\title{
PENGARUH PEMBERIAN MOTIVASI TERHADAP SEMANGAT HAFALAN AL-QUR'AN SISWI KELAS X AGAMA 2 MADRASAH ALIYAH AL-AMIRIYYAH BLOKAGUNG BANYUWANGI TAHUN AJARAN 2016/2017
}

\author{
Munawir \\ Institut Agama Islam Darussalam (IAIDA) Banyuwangi \\ Email: munawiriaida@gmail.com
}

\begin{abstract}
This research is directed at three main points, namely (1) to find out how motivation, (2) to determine how the spirit of memorization of the Qur'an, (3) there any influence of motivation on the spirit of the Qur'an recitation. This study uses a questionnaire with analysis techniques Product Moment. The study population was all students of class $X$ religions 2 Madrasah Aliyah Al-Amiriyyah amounting to 22 respondents as sample indeed. After analyzing the data collected, the researchers found that the provision of motivation $(X)$ greatly affects the spirit of memorization of the Qur'an $(Y)$ with a correlation value of 0.93 which indicates that this research is in excellent condition. Thus, it can be concluded that the motivating influence on the spirit of the Quran recitation class $X$ student of religion 2 Madrasah Aliyah Al-Amiriyyah Blokagung Banyuwangi.
\end{abstract}

Keywords: Motivation, Morale Memorizing the Qur'an.

\begin{abstract}
Abstrak
Penelitian ini diarahkan pada 3 hal pokok, yaitu (1) untuk mengetahui bagaimana pemberian motivasi, (2) untuk mengetahui bagaimana semangat hafalan AlQur'an, (3) adakah pengaruh motivasi terhadap semangat hafalan Al-Qur'an. Penelitian ini menggunakan metode kuesioner dengan teknik analisis Product Moment. Populasi penelitian ini adalah seluruh siswi kelas X agama 2 Madrasah Aliyah Al-Amiriyyah yang berjumlah 22 responden sebagai sempel ssungguhnya. Setelah melakukan analisa data yang dikumpulkan, peneliti menemukan bahwa pemberian motivasi $(X)$ sangat berpengaruh terhadap semangat hafalan AlQur'an $(Y)$ dengan nilai korelasi sebesar 0,93 yang mengindikasikan bahwa penelitian ini tergolong sangat baik. Dengan demikian, dapat disimpulkan bahwa pemberian motivasi sangat berpengaruh terhadap semangat hafalan Al-Qur'an siswi kelas X agama 2 Madrasah Aliyah Al-Amiriyyah Blokagung Banyuwangi.
\end{abstract}

Kata Kunci : Motivasi, Semangat Hafalan Al-Qur'an.

\section{A. Latar Belakang}

Pengajaran tradisional meniti beratkan pada metode imposisi, yakni pengajaran dengan cara menuangkan hal-hal yang dianggap penting oleh guru dan murid. Sejak adanya penemuan-penemuan baru dalam bidang psikologi tentang 
kepribadian dan tingkah laku manusia, serta perkembangan dalam bidang ilmu pendidikan maka pandangan tersebut kemudian berubah. Faktor siswa didik justru menjadi unsur yang menentukan berhasil atau tidaknya pengajaran yang disampaikan oleh guru. Motivasi memiliki dua komponen, yakni kompenan dalam (inner component), dan komponen luar (outer component). Komponen dalam ialah perubahan dalam diri seseorang, keadaan merasa tidak puas, dan ketegangan psikologis. Komponen luar ialah apa yang diinginkan seseorang, tujuan yang menjadi arah kelakuanya. Jadi, komponen dalam ialah kebutuhan-kebutuhan yang ingin dipuaskan, sedangkan komponen luar ialah tujuan yang hendak dicapai.

Keberhasilan suatu bangsa dalam melaksanakan pembangunan bergantung pada kualitas manusianya. Sementara untuk mendapatkan manusia yang berkualitas harus melalui proses yang membutuhkan pengorbanan pada setiap jenjang pendidikan. Dalam proses tersebut manusia dibimbing dan diarahkan oleh penggerak, yang tidak lain adalah guru atau tenaga pengajar. Di Madrasah Aliyah Al-Amiriyyah yang berada di naungan Yayasan Pondok Pesantren Darusslam Blokagung kebanyakan siswa-siawinya merupakan santri yang setiap harinya tidak terlepas dari kegiatan mengaji dan juga belajar mengajar untuk menunjang santri agar berwawasan unggul dalam bidang agama maupun ilmu yang lainya. Madrasah Aliyah Al-Amiriyyah mempunyai program unggulan yakni Tahfidul Qur'an program tersebut diperuntukan untuk para santri yang berminat untuk menjadi $h u f a d z$ yang unggul

Menghafal Al-Qur'an merupakan pekerjaan yang cenderung sangat sulit dari pada membaca dan memahaminya. Hal ini terjadi karena selain memiliki lembaran yang sangat banyak, Al-Qur'an memiliki nuansa bahasa yang sangat relatif sulit untuk dipahami dan memiliki ayat-ayat yang mirip. Menghafal membutuhkan proses yang cukup lama, ketekunan dan keseungguhan sangat diperlukan sekali, usaha yang keras, ingatan yang kuat serta minat dan motivasi yang besar yang disesuaikan dengan kemampuan masing-masing orang. Sehingga tidak jarang banyak santri yang berhenti di tengah jalan sebelum menyelesaikan hafalan 30 juz. Hal tersebut dikarenakan kurangnya tekad, kurangnya motivasi dari dalam diri dan dari orang dekat, dan yang paling pokok yang menjadi problematika para santri dalam menghafal Al-Qur'an biasanya malas dalam 
melakukan Muroja'ah yaitu mengulang kembali ayat-ayat yang sudah dihafal sehingga beban menjaga hafalan terasa berat sekali karena terlalu banyak yang dilupa hingga berhenti menjadi pilihan bagi mereka yang merasa sudah tidak mampu lagi.

Oleh karena itu dalam mencapai tujuan untuk menghafal Al-Qur'an 30 juz dalam jangka waktu tertentu dalam prosesnya membutuhkan motivator yang sekaligus menjadi pembimbing, serta metode yang pas, dan untuk membantu calon hafidhoh dalam menyelesaikan hafalannya sangat diperlukan bimbingan dan pembinaan secara terus menerus untuk mengontrol sejauh mana tingkat hafalan yang dicapai oleh santri. Dalam kaitanya pengaruh motivasi dan hafalan maka diperlukan kerjasama antara guru dengan seluruh elemen yang ada dan juga memberikan dorongan serta motivasi kepada para santri yang menghafalkan AlQur'an agar dapat menyelesaikan hafalanya.

\section{B. Rumusan Masalah.}

Berdasarkan latar belakang masalah tersebut, maka rumusan masalah dalam penelitian ini sebagai berikut :

1. Bagaimana pemberian motivasi siswi kelas $\mathrm{X}$ agama 2 Madrasah Aliyah Al-Amiriyyah Tahun Ajaran 2015/2016?

2. Bagaimana semangat hafalan Al-Qur'an siswi kelas $X$ agama 2 Madrash Aliyah Al-Amiriyyah Tahun Ajaran 2015/2016?

3. Adakah pengaruh pemberian motivasi terhadap semangat hafalan AlQur'an siswi kelas X agama 2 Madrasah Aliyah Al-Amiriyyah Tahun Ajaran 2015/2016?

\section{Tujuan Penelitian}

Adapun tujuan dalam penelitian ini adalah sebagai berikut :

1. Untuk mengetahui pemberian motivasi siswi kelas $X$ agama 2 Madrasah Aliyah Al-Amiriyyah Tahun Ajaran 2015/2016

2. Untuk mengetahui semangat hafalan Al-Qur'an siswi kelas $\mathrm{X}$ agama 2 Madrasah Aliyah Al-Amiriyyah Tahun Ajaran 2015/2016 
3. Untuk mengetahui pengaruh pemberian motivasi terhadap semangat hafalan kelas X agama 2 Madrasah Aliyah Al-Amiriyyah Tahun Ajaran $2015 / 2016$

\section{Kajian Pustaka}

\section{Motivasi}

\section{Pengertian Motivasi}

Sebelum menjelaskan pengertian motivasi penulis akan menjelaskan fungsi teori dalam penelitian ini, di antaranya:

a. Memperjelas dan mempertajam ruang lingkup variabel.

b. Memprediksi dan memandu untuk menemukan fakta untuk kemudian dipakai guna mermuskan hipotesis dan menyusun instrumen penelitian.

c. Mengontrol, membahas hasil penelitian, untuk kemudian dipakai dalam memberikan saran.

Menurut Mc. Donal motivasi adalah suatu perubahan energi dalam diri (pribadi) seseorang yang ditandai dengan timbulnya perasaan dan reaksi untuk mencapai tujuan Oemar Hamalik (2001:158). Menurut Amier Daien Indrakusuma motivasi adalah kekuatan-kekuatan atau tenaga-tenaga yang dapat memberikan dorongan kepada kegiatan murid (1973:162). Menurut Chalijah Hasan motivasi adalah daya dalam diri seseorang yang mendorongnya untuk melakukan sesuatu atau keadaan seseorang atau organisme yang menyeabkan kesiyapannya untuk melalui serangkaian tingkah laku atau perbuatan (1994:144)

\section{Fungsi Motivasi}

Motivasi merupakan salah satu unsur dalam mencapai prestasi belajar yang optimal selain kondisi kesehatan secara umum, intelegensi, dan bakat minat (Rustam:1988). Seorang anak didik bukan tidak bisa mengerjakan sesuatu, tetapi ketidak bisaan itu disebabkan oleh kemauan yang tidak terlalu banyak terhadap pekerjaan itu. Motif yang kurang menyebabkan dorongan dan kemauan tidak kuat, sehingga hasil kerjanya tidak sesuai dengan kecakapan. Menurut teori humanistic dari Maslow (Kolesnik:1970), motivasi seseorang berasal dari kebutuhannya, sehingga 
orientasi manusia berorientasi pada pemuasan kebutuhan dan pencapaian tujuan.

Dalam kegiatan belajar, motivasi dapat dikatakan sebagai keseluruhan daya penggerak dalam diri individu yang menimbulkan kegiatan belajar, yang menjamin kelangsungan kegiatan belajar dan yang memberikan arah pada kegiatan belajar sehingga tujuan yang dikehendaki akan tercapai (Sardiman:1990). Jika individu mempunyai motivasi belajar yang tinggi maka individu tersebut akan mencapai prestasi yang baik. Motivasi belajar merupakan faktor psikis yang bersifat non intelektual. Peranannya yang khas adalah dalam penumbuhan gairah, perasaaan, dan semangat untuk belajar. Motivasi belajar adalah dorongan yang menjadi penggerak dalam diri seseorang untuk melakukan sesuatu dan mencapai suatu tujuan yaitu untuk mencapai prestasi. Dengan demikian motivasi memiliki peran strategis dalam belajar, baik pada saat akan memulai pelajaran, saaat sedang belajar, maupun saat berakhirnya belajar. Menurut Sardiman (2003), ada tiga fungsi motivasi, yaitu:

1. Mendorong manusia untuk berbuat, jadi sebagai penggerak atau motor yang melepaskan energy. Motivasi dalam hal ini merupakan motor penggerak dari setiap kegiatan yang akan dikerjakan.

2. Menentukan arah perbuatan, yakni kearah tujuan yang hendak dicapai. Dengan demikian motivasi dapat memberikan arah dan kegiatan yang harus dikerjakan sesuai dengan rumusan tujuannya.

3. Menyeleksi perbuatan, yakni menentukan perbuatan-perbuatan apa saja yang harus dikerjakan yang serasi guna mencapai tujuan, dengan menyisihkan perbuatan-perbuatan yang tidak bermanfaat bagi tujuan tersebut.

\section{Nilai Motivasi}

Adalah menjadi tanggung jawab guru agar pengajaran yang diberikanya berhasil dengan baik. Keberhasilan ini banyak bergantung pada usaha guru membangkitkan motivasi belajar murid. Dalam garis besarnya motivasi mengandung nilai-nilai sebagai berikut : 
a. Motivasi menentukan tingkat berhasil atau gagalnya perbuatan belajar murid. Belajar tanpa adanya motivasi kiranya sulit akan berhasil.

b. Pengajaran yang bermotivasi pada hakikatnya adalah pengajaran yang disesuaikan dengan kebutuhan, dorongan, motif, minat yang ada pada murid. Pengajaran yang demikian sesuai dengan tuntutan demokrasi dalam pendidikan.

c. Pengajaran yang bermotivasi menuntut kreatifitas dan imajinasi guru untuk berusaha secara sungguh-sungguh mencari cara-cara yang relevan dan sesuai guna membangkitkan dan memelihara motivasi belajar siswa. Guru senantiasa berusaha agar murid-murid akhirnya memilki self motivasion yang baik.

d. Berhasil atau gagalnya dalam membangkitkan dan menggunakan motivasi dalam pengajaran erat pertalianya dengan pengaturan disiplin kelas. Kegagalan dalam hal ini mengakibatkan timbulnya masalah disiplin di dalam kelas.

\section{Prinsip Motivasi}

Prinsip-prinsip ini disusun atas dasar penelitian yang saksama dalam rangka mendorong motivasi belajar murid-murid disekolah yang mengandung pandangan demokratis dan dalam rangka menciptakan self motivasion dan self disiplin dikalangan murid-murid. Kenneth H. Hover, mengemukakan prinsip-prinsip motivasi sebagai berikut :

a. Pujian lebih efektif dari pada hukuman. Hukuman bersifat menghentikan sesuatu perbuatan, sedangkan pujian bersifat menghargai apa yang telah dilakukan. Karena itu pujian lebih besar nilainya bagi motivasi belajar murid.

b. Semua murid mempunyai kebutuhan-kebutuhan psikologis (yang bersifat dasar) tertentu yang harus mendapatkan kepuasan.

Kebutuhan-kebutuhan itu menyatakan diri dalam berbagai bentuk yang berbeda. Murid-murid yang dapat memenuhi kebutuhannya secara efektif melalui kegiatan-kegiatan belajar hanya memerlukan sedikit bantuan di dalam motivasi dan disiplin. 


\section{Klasifikasi Motivasi}

Motivasi dibedakan menjadi dua yaitu :

a. Motivasi Instrinsik

Motivasi instrinsik adalah motivasi yang timbul dari dalam diri sendiri, tanpa ada dorongan atau paksaan dari orang lain. Misalnya : seorang anak mau belajar karena ingin mendapatkan pemahaman pada suatu materi pelajaran. Karena itu ia rajin belajar tanpa ada seruan atau dorongan dari orang lain. (Amier Daien Indrakusuma,1973:163).

Menurut Hamalik (2001:162) motivasi instrinsik adalah motivasi yang tercakup di dalam situasi belajar dan menemui kebutuhan dan tujuan murid. Motivasi ini sering juga disebut motivasi murni. Motivasi yang sebenarnya yang timbul dalam diri siswa sendiri, misalnya keinginan untuk mendapatkan keterampilan tertentu, memperoleh informasi dan pengertian, mengembangkan sikap untuk berhasil, menyenangi kehidupan, menyadari sumbanganya terhadp kelompok, keinginana diterima oleh orang lain, dan lain-lain.

b. Motivasi Ekstrinsik

Motivsi Ekstrinsink adalah motivasi atau tenaga-tenaga pendorong yang berasal dari luar diri sendiri. Misalnya : seseorang siswa belajar karena disuruh orang tuanya agar mendapatkan hasil yang maksimal. Motivasi Ekstrinsik Menurut Hamalik (2001:163) adalah motivasi yang disebabkan oleh faktor-faktor dari luar situasi belajar, seperti angka kredit, ijazah, tingkatan hadiah, dan hukuman. Motivasi ekstrinsik ini tetap diperlukan disekolah, sebab pengajaran disekolah tidak semuanya menarik minat siswa atau kebutuhan siswa. Lagi pula sering kali para siswa belum memahami untuk apa dia belajar hal-hal yang diberikan oleh sekolah.

Karena itu motivasi terhadap pelajaran itu perlu dibangkitkan oleh guru sehingga siswa mau dan ingin belajar. Usaha yang dikerjakan oleh guru sangat banyak, dan karean itu di dalam memotivasi siswa kita tidak akan menentukan suatu formula tertentu yang digunakan setiap saat oleh guru. Dari uraian di atas 
sesungguhnya sulit untuk menentukan yang lebih baik, moitivasi intrinsik atau ekstrinsitik.

\section{Hafalan Al-Qur'an}

\section{Pengertian Metode Tahfidz Al-Qur'an}

Tahfidz al-Qur'an terdiri dari dua kata yaitu tahfidz dan al- Qur'an. Kata tahfidz merupakan bentuk masdar ghoiru mim dari kata yang mempunyai arti menghafalkan. Tahfidz atau menghafal Al-Qur'an merupakan suatu perbuatan yang sangat mulia dan terpuji. Sebab, orang yang menghafal Al-Qur'an merupakan salah satu hamba yang ahlullah di muka bumi. Dengan demikian pengertian Tahfidz yaitu menghafal materi baru yang belum pernah dihafal.

Hafalan adalah juga memori tetapi prosesnya berbeda. Memori bisa terbentuk tanpa kita mengadakan suatu usaha khusus untuk memperolehnya. Kalau seseorang menceritakan kejadian yang terjadi padanya tadi pagi, kejadian itu akan dapat masuk ke dalam memori kita hanya dari mendengarkan cerita itu. Sebaliknya, hafalan hanya akan dapat menjadi memori dengan suatu usaha atau tindakan yang khusus. Seorang aktor harus mempelajari berulang-ulang (menghafalkan) naskah yang akan diucapkannya. Dia menyimpan hafalan itu dalam memorinya.

\section{Konsep Menghafal Al-Qur'an}

Sebelum memulai menghafal Al-Qur'an, maka terlebih dahulu santri membaca mushaf Al-Qur'an dengan melihat ayat Al-Qur'an (Binadhor) dihadapan guru atau kyai. Sebelum memperdengarkan dengan hafalan yang baru, terlebih dahulu penghafal Al-Qur'an menghafal sendiri materi yang akan disemak dihadapan guru atau kyai.

\section{Metode Tahfidz Al-Qur'an}

Sebenarnya banyak sekali metode khusus dalam menghafal AlQur'an. Namun, dalam buku ( Mukhlisoh Zawawie:2011) hanya akan menguraikan beberapa metode yang paling banyak dilakukan dan berhasil mencetak Huffazh. Oleh karena itu, para pencinta Al-Qur'an yang ingin menghafalkan Al-Qur'an bisa memilih metode mana yang 
paling cocok untuk dirinya, atau bisa juga menggabung-gabungkan antara satu metode dengan lainnya sehingga akan lebih memperkuat hafalan yang telah dicapai.

\section{Manajemen Menghafal Al-Qur'an}

a. Manajemen Waktu

Pada dasarnya pilihan waktu yang tepat untuk menghafal sangat tergantung kepada kenyamanan dan kondisi pribadi masing-masing. Umumnya, orang yang menghafalkan Al-Quran di pesantrenpesantren menghabiskan waktu 3-4 tahun dengan program takhashshus (tahfidz intensif/sebagian waktunya untuk menghafal). Sebenarnya, kalau seseorang mampu mengatur waktu dengan baik, pasti akan jauh lebih cepat dari waktu tersebut. Misalnya, dalam sehari dia menambah hafalan dua halaman, maka dalam kurun waktu sepuluh bulan (atau max. 12 bulan) sudah tuntas 30 juz. Atau paling tidak, jika perhari menambah hafalan baru setengah halaman, maka dalam waktu 40 bulan ( 3 tahun 4 bulan atau max. 4 tahun) bisa tuntas semua. Tentu, dengan syarat setiap waktu terbuang harus diganti atau dirangkap tanpa kompromi.

b. Manajemen Strategi

Sebenarnya banyak sekali metode yang bisa digunakan untuk menghafal Al-Quran, Masing-masing orang akan mengambil metode yang sesuai dengan kondisi masing-masing. Di sini akan disebutkan dua metode yang sering dipakai oleh sebagian penghafal, dan terbukti sangat efektif, yaitu :

1. Menghafal satu persatu halaman (menggunakan Mushaf Madinah atau Menara Kudus). Kita membaca satu halaman yang akan kita hafal sebanyak tiga atau lima kali, setelah itu kita baru mulai menghafal. Setelah hafal satu halaman, baru kita pindah kepada halaman berikutnya dengan cara yang sama. Dan hindari pindah ke halaman berikutnya dalam kondisi hafalan yang labil (belum kuat), agar beban hafalan baru tidak menumpuk. 
2. Menghafal ayat per ayat, yaitu membaca satu ayat yang mau kita hafal tiga atau lima kali secara benar, setelah itu, kita baru menghafal ayat tersebut. Setelah selesai, kita pindah ke ayat berikutnya dengan cara yang sama, dan begitu seterusnya sampai satu halaman. Akan tetapi sebelum pindah ke ayat berikutnya kita harus mengulangi apa yang sudah kita hafal dari ayat sebelumnya. Setelah satu halaman, maka kita mengulanginya sebagaimana yang telah diterangkan pada metode pertama.

c. Manajemen Istiqamah

Setelah Al-Quran dihafal secara penuh (30 juz), seringkali seorang hafidz disibukkan oleh studinya, kegiatan rumah tangga atau sibuk dengan pekerjaan, sehingga kerap kali Al-Qur'an yang sudah dihafalnya beberapa tahun, akhirnya hanya tinggal kenangan saja. Yang terpenting dalam hal ini bukanlah menghafal, karena banyak orang mampu menghafal Al-Quran dalam waktu yang sangat singkat, akan tetapi yang paling penting adalah bagaimana kita melestarikan hafalan tersebut agar tetap terus ada dalam dada kita.

d. Manajemen Tempat

Tempat yang kondusif akan memberikan pengaruh signifikan terhadap kesuksesan menghafal. Mereka yang tinggal di lingkungan yang acuh tak acuh atau bahkan anti mendengar lantunan Al-Quran, akan merasa canggung untuk menghafal setiap saat. Sebaliknya mereka yang tinggal di pesantren khusus tahfidz, akan merasakan sebuah lingkungan yang kondusif, mau menghafal kapan saja dan di mana saja dan dengan cara apapun, dan hal itu tidak ada problem.

Secara umum, tempat yang paling kondusif untuk menghafal adalah masjid. Namun, kadang masing-masing orang memiliki selera dan tingkat kejenuhan yang berbeda, sehingga diperlukan alternatif tempat lain yang sunyi, seperti : di sawah, sungai, pesisir, makam, terutama makam ulama-ulama terkenal, seperti makam syeikh Hasyim Asyari Jombang yang sering dipakai tempat menghafal oleh santrisantri Pesantren "Madrasatul Al-Quran". Juga makam KH. Muchtar 
Syafa'at Blokagung yang sering digunakan sebagai tempat menghafal bagi santri-santri yang berkeinginan menjadi hufadz Al-Qur'an.

\section{E. Metode Penelitian}

\section{Jenis Dan Langkah-Langkah Penelitian}

Untuk memudahkan proses pelaksanaan penelitian, maka perlu dibuat sebuah rancangan penelitian. Karena pengupulan data yang efisien hanya mungkin dilakukan bila peneliti mengerti betul pokok permasalahan yang menjadi obyek penelitian. Rancangan langkah-langkah penelitian ini merupakan pedoman dalam melakukana kegiatan penelitian guna mendapatkan data dengan efesien, terarah, dan ekonomis. Pada hakikatnya penelitian adalah suatu cara dari berbagai macam cara yang pernah ditempuh dalam mencari kebenaran. Cara mendapatkan kebenaran tersebut ditempuh melalui metode ilmiah. Jadi tidak berlebihan apabila metode tersebut sebagai setrategi dalam penelitian ilmiah. Tujuanya untuk meramalkan, megontrol, dan menjelaskan gejela-gejala yang teramati guna untuk mendapatkan kebenaran yang kita inginkan. Mengenai metode itu sendiri Mardalis (2006: 24), berpendapat bahwa, "Metode adalah suatu cara teknis yang dilakukan dalam proses penelitian, sedangkan Penelitian adalah upaya dalam bidang ilmu pengetahuan yang dijalankan untuk memperoleh fakta-fakta dan prinsip-prinsip dengan sabar, hati-hati dan sistematis untuk mewujudkan kebenaran". Sedangkan Margono berpendapat bahwa "Penelitian adalah semua kegiatan pencarian, penyelidikan, dan percobaan secara ilmiah dalam suatu bidang tertentu, untuk mendapatkan fakta-fakta atau prinsip-prinsip baru yang bertujuan untuk mendapatkan penertian baru dan menaikkan ilmu serta teknologi” (2004: 1)

\section{Populasi Dan Sampel}

Margono (2004: 118) memberikan penjelasan, Dalam Kamus Besar Bahasa Indonesia adalah "sekelompok orang, benda atau hal yang menjadi sumber pengambilan sampel suatu kumpualan yang memenuhi syarad tertentu yang berkaitan dengan masalah penelitian. Suharsimi Arikunto (2006:130) berpendapat bahwa Populasi adalah "keseluruhan objek penelitian". Menurut Mardalis (2006:53) poulasi adalah "sekumpulan kasus yang perlu memenuhi syarat-syarat tertentu yang berkaitan dengan masalah penelitian. Kasus tersebut dapat berupa orang, binatang, hal atau peristiwa. 
Sedangkan menurut Amirul Hadi (2005:83) populasi adalalah "semua nilai, baik hasil pengitungan atau pengukuran, baik kuantitatif maupun kualitatif, karekteristik tertentu mengeni sekelompok objek yang lengkap dan jelas”. "Populasi adalah seluruh data yang menjadi perhatian kita dalam suatu ruang lingkup dan waktu yang ditentukan”. Pendapat tersebut sama halnya dengan populasi adalah keseluruhan subyek atau obyek yang menjadi sasaran penelitian. (Soepeno, 2002: 82).

\section{Instrumen Penelitian}

Dalam Kamus Besar Bahasa Indonesia disebutkan bahwa pengertian dari insrumen adalah sebuah alat yang digunakan untuk mengumpulkan data sebagai bahan pengolahan. Sukidin dan Mundir (2005:220) di dalam buku Meode penelitian mengemukakan instrumen yang baik yaitu "instrumen yang memiliki 2 kriteria, yaitu valid (sahih) dan reliabel (dapat dipercaya)". Valid atau validitas adalah suatu ukuran yang menunjukan tingkat kesahihan suatu instrumen. Instrumen dikatakan valid apabila mampu mengukur apa yang diinginkan, dapat mengungkap data dari variabel terteliti secara cepat. Pada umumnya penelitian akan berhasil apabila banyak menggunakan instrument, sebab data yang digunakan untuk menjawab pertanyaan penelitian (masalah) dan menguji hipotesis diperoleh melalui instrumen.

\section{Teknik Pegumpulan Data}

Dalam setiap penelitian disamping menggunakan metode yang tepat diperlukan kemampuan memilih, menyusun dan mengunakan alat pengumpulan data yang relevan. Sehingga dalam suatu penelitian akan memungkinkan dicapainya pemecahan masalah yang valid, yang nantinya akan memungkinkan munculnya generalisasi yang obyektif. Adapun teknik dan alat pengumpulan data yang dipergunakan dalam penelitian ini adalah observasi, interview, angket, dan dokumenter.

\section{Uji Validitas Instrumen}

Dalam melakukan penelitian, peneliti dapat memutuskan untuk menggunakan instrument penelitian yang sudah terstandar atau mengembangkan instrumen penelitian sendiri. Ketika akan mengembangkan instrument penelitian sendiri, kita perlu berusaha untuk mengetahui kualitas instrumen yang kita 
kembangkan sebelum digunakan dalam pengumpulan data yang sebenarnya. Tujuannya tentu saja untuk memastikan agar instrumen yang kita kembangkan akan dapat menjaring informasi yang kita inginkan. Durri Andriani, dkk (2011:5.27) menyimpulkan, "kualitas instrument dapat diketahui dengan cara menghitung validitas instrument. Adapun validitas instrument adalah keabsahan suatu instrument dalam mengukur apa yang hendak kita ukur”. Adapun uji validitas instrumen yang peneliti gunakan dalam penelitian ini dengan menggunakan rumus validitas yang mengacu pada nilai t hitung dan t tabel adapun kriteria kevalidan data di tentukan dengan kriteria sebagai berikut:

1. Jika nilai t hitung pada skor jawaban angket penelitian lebih besar dari t tabel $(1,701)$ maka data tersebut dinyatakan valid.

2. Jika nilai t hitung pada skor jawaban angket penelitian lebih kecil dari t tabel $(1,701)$ maka data tersebut dinyatakan tidak valid.

Oleh karena itu uji validitas instrumen adalah hal yang sangat penting dalam sebuah penelitian guna mendapatkan hasil penelitian yang akurat dan jelas serta tidak akan mempunyai arti apa-apa jika alat ukurnya tidak valid.

\section{Teknik Analisis Data}

Sudjana (2008:76) berpendapat analisis data adalah proses penyusunan, pengaturan, dan pengelompokan agar data dapat digunakan untuk membenarkan atau menyalahkan hipotesis. Berdasarkan pendapat-pendapat diatas maka dapat diketahui bahwa statiktik adalah suatu alat untuk menarik kesimpulan dan datadata berupa angka (kuantitatif) atau bukan angka (kualitatif) tetapi sudah diubah menjadi data yang berupa angka, dengan menggunakan rumus tertentu. Adapun tehnik analisa data yang penulis gunakan adalah. "Korelasi Pearson Product Moment (PPM) anggka kasar.” Karena penelitian dalam skripsi ini untuk mencari hubungan atau korelasi antara variabel bebas dengan fariabel terikat.

Atas alasan itu peneliti menggunakan rumus sebagai berikut:

$$
\begin{aligned}
\mathrm{r}_{\mathrm{xy}}= & \mathrm{N} \sum \mathrm{xy}-\left(\sum \mathrm{x}\right)\left(\sum \mathrm{y}\right) \\
& \frac{\sqrt{\left\{\sum \mathrm{x}^{2}-\left(\sum \mathrm{y}\right)^{2}\right\}\left\{\mathrm{N} \sum \mathrm{y}^{2}-\left(\sum y\right)^{2}\right\}}}{\operatorname{Ketengan}^{2}}
\end{aligned}
$$

\section{Keterangan:}


$\mathrm{r}_{\mathrm{xy}} \quad$ : korelasi antara variabel $\mathrm{x}$ dengan $\mathrm{y}$

$\sum x y \quad$ : jumlah perkalian skor c dengan y

$\sum \mathrm{x} 2$ : jumlah kuadrat skor $\mathrm{x}$

$\sum y 2$ : jumlah kuadrat skor distribusi : y

Setelah diperoleh nilai "r", langkah selanjutnya adalah dikonsultasikan kedalam tabel interpretasi nilai "r". Adapun Tabel interpretasi sebagai berikut:

\section{Tabel 1 Pedoman Untuk Menentukan Interpretasi Skor Variabel X dan Y}

\begin{tabular}{|c|c|}
\hline Besarnya Skor & Interpretasi \\
\hline $81 \%-100 \%$ & Sangat baik \\
\hline $61 \%-80 \%$ & Baik \\
\hline $41 \%-61$ & Cukup \\
\hline $21 \%-40 \%$ & Buruk \\
\hline $0 \%-20 \%$ & Sangat buruk \\
\hline
\end{tabular}

(Sugiyono, 2015:257)

Sedangkan untuk mengetahui interpretasi skor dari masing masing variabel baik variabel x ataupun variabel y dapat di konsultasikan dengan menggunakan tabil di bawah ini:

\section{Tabel 2 Pedoman Untuk Memberikan Interpretasi Koefisien Korelasi $\mathbf{r}$}

\begin{tabular}{|c|c|}
\hline Interval Koefisien & Tingkat Hubungan \\
\hline $0,00-0,199$ & Sangat buruk \\
\hline $0,20-0,399$ & Buruk \\
\hline $0,40-0,599$ & Sedang \\
\hline $0,60-0,799$ & Baik \\
\hline $0,80-1,000$ & Sangat baik \\
\hline
\end{tabular}

(Sugiono, 2015:257)

Kemudian untuk menguji signifikasi nilai $r$ hitung dapat di konsultasikan mengunakan tabel nilai $\mathrm{r}$ product moment dengan kriteria sebagai berikut :

1. jika nilai $r$ hitung lebih besar dari nilai $r$ tabel maka dikatakan signifikan.

2. jika nilai $r$ hinting lebih kecil dari nilai $r$ tabel maka nilai tersebut di katakan tidak signifikan 


\section{F. Hasil Dan Pembahasan}

Adapun skala pengukuran pada penelitian ini menggunakan skala likert yaitu teknik pengukuran yang mengabungkan skala-skala yang ada untuk itu digunakan interval 1-5 untuk jawaban responden dengan menghilangkan alternatif jawaban ragu-ragu adalah modifikasi dari skala likert. Yang bertujuan untuk menghilangkan munculnya kecendrungan responden menjawab alternatif yang ada ditengah, sehingga dapat mengurangi kevalitan informasi yang didapat. Menurut Hadi (1990), modifikasi skala likert dengan meniadakan jawaban ditengah memiliki beberapa alasan, yaitu:

1. Kategori jawaban yang ganda arti (tidak memutuskan atau raguragu) tidak diharapkan dalam suatu instumen.

2. Tersedianya jawaban ditengah menimbulkan kecenderungan menjawab ketengah, Terutama yang menjawab ragu-ragu untuk menjawab setuju atau tidak setuju.

3. Kategori menjawab seperti sangat setuju , setuju, kurang setuju atau netral, tidak setuju, sangat tidak sertuju terutama melihat kecendrungan pendapat responden. Jika tersedia kategori jawaban ditengah maka akan banyak menghilangkan data penelitian sehingga mengurangi banyaknya informasi yang akan dijaring dari para responden.

Sebelum dikemukakan table skor data hasil penyebaran angket, kami akan kemukakan beberapa penjelasan dan ketentuan sebagai berikut:

1. Jumlah pertanyaan angket seluruhnya ada 10 item pertanyaan

2. Dari masing-masing pernyataan, terdiri dari 5 (alternatif) jawaban yaitu: a,b,c,d, dan e dengan bobot skor (penilaian) sebagai berikut :
a) Jika responden memilih alternatif A diberi skor 5
b) Jika responden memilih alternatif B diberi skor 4
c) Jika responden memilih alternatif $\mathrm{C}$ diberi skor 3
d) Jika responden memilih alternatif D diberi skor 2
e) Jika responden memilih alternatif E diberi skor 1

Sedangkan nama responden sesuai dengan perincian tersebut dapat dilihat pada table berikut ini. 
Tabel 3

Rekapitulasi Jawaban Responden Tentang Pemberian Motivasi(Varibel X)

\begin{tabular}{|c|c|c|c|c|c|c|c|c|c|c|c|}
\hline \multirow{2}{*}{$\begin{array}{l}\text { No. } \\
\text { Resp }\end{array}$} & \multicolumn{10}{|c|}{ No. Item \& Skor } & \multirow{2}{*}{ Jumlah } \\
\hline & 1 & 2 & 3 & 4 & 5 & 6 & 7 & 8 & 9 & 10 & \\
\hline 1 & 5 & 4 & 5 & 5 & 5 & 5 & 5 & 5 & 5 & 5 & 49 \\
\hline 2 & 5 & 4 & 5 & 5 & 4 & 5 & 5 & 4 & 5 & 5 & 47 \\
\hline 3 & 5 & 5 & 5 & 5 & 4 & 5 & 5 & 5 & 5 & 5 & 49 \\
\hline 4 & 5 & 5 & 5 & 5 & 5 & 4 & 4 & 5 & 5 & 5 & 48 \\
\hline 5 & 4 & 4 & 5 & 5 & 4 & 5 & 5 & 4 & 4 & 4 & 44 \\
\hline 6 & 5 & 5 & 4 & 5 & 5 & 5 & 5 & 3 & 5 & 5 & 47 \\
\hline 7 & 5 & 5 & 5 & 5 & 5 & 5 & 5 & 5 & 5 & 5 & 50 \\
\hline 8 & 5 & 5 & 3 & 5 & 4 & 5 & 4 & 4 & 4 & 4 & 43 \\
\hline 9 & 5 & 5 & 5 & 5 & 5 & 5 & 5 & 5 & 5 & 5 & 50 \\
\hline 10 & 5 & 5 & 5 & 5 & 5 & 5 & 5 & 5 & 4 & 4 & 48 \\
\hline 11 & 4 & 4 & 4 & 5 & 5 & 5 & 4 & 4 & 5 & 5 & 45 \\
\hline 12 & 5 & 4 & 4 & 4 & 5 & 4 & 4 & 5 & 4 & 4 & 43 \\
\hline 13 & 5 & 4 & 5 & 5 & 5 & 5 & 5 & 5 & 3 & 4 & 46 \\
\hline 14 & 5 & 4 & 4 & 5 & 5 & 4 & 5 & 3 & 4 & 5 & 44 \\
\hline 15 & 5 & 5 & 5 & 5 & 5 & 5 & 5 & 5 & 5 & 5 & 50 \\
\hline 16 & 5 & 5 & 4 & 5 & 5 & 5 & 5 & 3 & 5 & 3 & 45 \\
\hline 17 & 5 & 5 & 5 & 5 & 5 & 5 & 4 & 5 & 4 & 4 & 47 \\
\hline 18 & 5 & 5 & 5 & 5 & 5 & 5 & 5 & 5 & 5 & 5 & 50 \\
\hline 19 & 5 & 3 & 4 & 5 & 5 & 5 & 5 & 4 & 5 & 5 & 46 \\
\hline 20 & 5 & 4 & 5 & 5 & 5 & 5 & 5 & 4 & 4 & 5 & 47 \\
\hline 21 & 4 & 2 & 2 & 2 & 2 & 3 & 3 & 2 & 1 & 4 & 25 \\
\hline 22 & 5 & 4 & 5 & 5 & 5 & 5 & 4 & 4 & 5 & 4 & 46 \\
\hline \multicolumn{11}{|c|}{ Total } & 1009 \\
\hline \multicolumn{11}{|c|}{ Rata-rata } & 45,86 \\
\hline
\end{tabular}

Kategori nilai:

Rata-rata $=$ Jumlah $:$ Responden $(\mathrm{N})=1009: 22=45,86=46$

Tabel 4

Tabel Tentang Kategorisasi

\begin{tabular}{|l|l|}
\hline Interval & Kategori \\
\hline $38-50$ & Baik \\
$24-37$ & Sedang \\
$10-23$ & Kurang \\
\hline
\end{tabular}

(Olahan Peneliti) 
Berdasarkan hasil jawaban responden atau questioner tentang pengaruh pemberian motivasi diperoleh skor rata-rata " 45,86 ", jika dikonsultasikan dengan kategori nilai skor berada di interval 38-50 maka memiliki kategori "Baik".

Tabel 5

\section{Rekapitulasi Jawaban Responden Tentang Semangat Hafalan Al-Qur'an} (Varibel Y)

\begin{tabular}{|c|c|c|c|c|c|c|c|c|c|c|c|}
\hline \multirow{2}{*}{ No. Resp } & \multicolumn{10}{|c|}{ No. Item \& Skor } & \multirow{2}{*}{ Jumlah } \\
\hline & 1 & 2 & 3 & 4 & 5 & 6 & 7 & 8 & 9 & 10 & \\
\hline 1 & 5 & 5 & 5 & 5 & 5 & 5 & 5 & 5 & 5 & 5 & 50 \\
\hline 2 & 5 & 5 & 5 & 5 & 5 & 4 & 4 & 5 & 5 & 5 & 48 \\
\hline 3 & 5 & 5 & 5 & 5 & 5 & 5 & 5 & 5 & 5 & 5 & 50 \\
\hline 4 & 5 & 5 & 5 & 5 & 5 & 5 & 5 & 5 & 5 & 5 & 50 \\
\hline 5 & 5 & 5 & 5 & 5 & 3 & 2 & 5 & 5 & 5 & 5 & 45 \\
\hline 6 & 5 & 5 & 5 & 5 & 5 & 5 & 5 & 4 & 5 & 5 & 49 \\
\hline 7 & 5 & 5 & 5 & 5 & 5 & 5 & 5 & 5 & 5 & 5 & 50 \\
\hline 8 & 5 & 5 & 5 & 4 & 5 & 4 & 5 & 5 & 5 & 5 & 48 \\
\hline 9 & 5 & 5 & 5 & 5 & 5 & 5 & 5 & 5 & 5 & 5 & 50 \\
\hline 10 & 5 & 5 & 5 & 5 & 5 & 5 & 5 & 5 & 5 & 4 & 49 \\
\hline 11 & 5 & 5 & 5 & 5 & 5 & 4 & 4 & 5 & 5 & 5 & 48 \\
\hline 12 & 4 & 5 & 5 & 5 & 5 & 5 & 5 & 5 & 5 & 5 & 49 \\
\hline 13 & 5 & 3 & 4 & 5 & 5 & 5 & 5 & 5 & 5 & 5 & 47 \\
\hline 14 & 5 & 5 & 4 & 4 & 5 & 5 & 4 & 5 & 5 & 5 & 47 \\
\hline 15 & 5 & 5 & 5 & 5 & 5 & 5 & 5 & 5 & 5 & 5 & 50 \\
\hline 16 & 4 & 5 & 4 & 5 & 5 & 5 & 5 & 5 & 5 & 5 & 48 \\
\hline 17 & 4 & 5 & 5 & 5 & 5 & 5 & 5 & 5 & 5 & 5 & 49 \\
\hline 18 & 5 & 5 & 5 & 5 & 5 & 5 & 5 & 5 & 5 & 5 & 50 \\
\hline 19 & 5 & 4 & 4 & 5 & 5 & 5 & 5 & 5 & 5 & 5 & 48 \\
\hline 20 & 5 & 5 & 5 & 4 & 5 & 5 & 5 & 5 & 5 & 5 & 49 \\
\hline 21 & 4 & 4 & 4 & 4 & 4 & 3 & 3 & 4 & 4 & 4 & 38 \\
\hline 22 & 5 & 5 & 4 & 5 & 5 & 5 & 5 & 5 & 5 & 5 & 49 \\
\hline \multicolumn{11}{|c|}{ Total } & 1062 \\
\hline \multicolumn{11}{|c|}{ Rata-rata } & 48,27 \\
\hline
\end{tabular}

Kategori nilai:

Rata-rata $=$ Jumlah $:$ Responden $(\mathrm{N})=1062: 22=48,27=48$ 
Tabel 6

Tabel Tentang Kategorisasi

\begin{tabular}{|l|l|}
\hline Interval & Kategori \\
\hline $38-50$ & Baik \\
$24-37$ & Sedang \\
$10-23$ & Kurang \\
\hline
\end{tabular}

(Olahan Peneliti)

Berdasarkan hasil jawaban responden atau questioner tentang semangat hafalan Al-Qur'an diperoleh skor rata-rata “48,27”, jika dikonsultasikan dengan kategori nilai skor berada di interval 38-50 maka memiliki kategori "Baik".

\section{G. Analisis Data dan Pengujian Hipotesis}

Setelah menyajikan scorsing data penyebaran angket pengaruh pemberian motifasi terhadap semangat hafalan Al-Qur'an siswi kelas X agama 2 Madrasah Aliyah Al-Amiriyyah Tahun Ajaran 2015/2016. Maka selanjutnya dipersiapkan tabel penolong untuk menganalisa dan pengujian hipotesa yang diajukan. Namun sebelum dianalisis, maka hipotesa kerja $(\mathrm{Ha})$ yaitu adanya pengaruh pemberian motifasi terhadap semangat hafalan Al-Qur'an siswi kelas X agama 2 Madrasah Aliyah Al-Amiriyyah tahun Ajaran 2015/2016, yang diajukan sebagai hipotesa alternatif sebelum diuji kebenarannya terlebih dahulu diubah menjadi hipotesa nihil (Ho). Hal ini dikarenakan analisa yang digunakan adalah menggunakan analisa statistik sehingga hipotesa nihil yang diajukan sebagai berikut : Hipotesa Nihil (Ho) tidak adanya pengaruh pemberian motifasi terhadap semangat hafalan Al-Qur'an siswi kelas X agama 2 Madrasah Aliyah Al-Amiriyyah Tahun Ajaran 2015/2016, Selanjutnya untuk menghitung koefesien pengaruh, Langkah pertama kami dalam analisis data ini adalah mencari hubungan variabel bebas (X) dengan variabel terikat (Y) dan data berbentuk interval dan ratio dengan menggunakan rumus korelasi product moment, adapun perhitungannya sebgai berikut : 
Tabel 7

Tabel Korelasi Variabel (X) dan Varibel (Y)

\begin{tabular}{|c|c|c|c|c|c|}
\hline No. & $\mathbf{X}$ & $\mathbf{Y}$ & $\mathrm{X}^{2}$ & $\mathbf{Y}^{2}$ & XY \\
\hline 1 & 49 & 50 & 2401 & 2500 & 2450 \\
\hline 2 & 47 & 48 & 2209 & 2304 & 2256 \\
\hline 3 & 49 & 50 & 2401 & 2500 & 2450 \\
\hline 4 & 48 & 50 & 2304 & 2500 & 2400 \\
\hline 5 & 44 & 45 & 1936 & 2025 & 1980 \\
\hline 6 & 47 & 49 & 2209 & 2401 & 2303 \\
\hline 7 & 50 & 50 & 2500 & 2500 & 2500 \\
\hline 8 & 43 & 48 & 1849 & 2304 & 2064 \\
\hline 9 & 50 & 50 & 2500 & 2500 & 2500 \\
\hline 10 & 48 & 49 & 2304 & 2401 & 2352 \\
\hline 11 & 45 & 48 & 2025 & 2304 & 2160 \\
\hline 12 & 43 & 49 & 1849 & 2401 & 2107 \\
\hline 13 & 46 & 47 & 2116 & 2209 & 2162 \\
\hline 14 & 44 & 47 & 1936 & 2209 & 2068 \\
\hline 15 & 50 & 50 & 2500 & 2500 & 2500 \\
\hline 16 & 45 & 48 & 2025 & 2304 & 2160 \\
\hline 17 & 47 & 49 & 2209 & 2401 & 2303 \\
\hline 18 & 50 & 50 & 2500 & 2500 & 2500 \\
\hline 19 & 46 & 50 & 2116 & 2500 & 2300 \\
\hline 20 & 47 & 48 & 2209 & 2304 & 2256 \\
\hline 21 & 25 & 38 & 625 & 1444 & 950 \\
\hline 22 & 46 & 49 & 2116 & 2401 & 2254 \\
\hline Total & 1009 & 1062 & 46839 & 51412 & 48975 \\
\hline
\end{tabular}

Keterangan :

$\mathrm{X}$ : Nilai pengaruh pemberian motivasi

Y : Nilai semangat hafalan al-Qur'an

$$
\begin{aligned}
& r_{x y}=\frac{n \sum x y-\left(\sum x\right)\left(\sum y\right)}{\sqrt{\left\{n \sum x^{2}-\left(\sum x\right)^{2}\right\}\left\{n \sum y^{2}-\left(\sum y\right)^{2}\right\}}} \\
& r_{x y}=\frac{(22.48975)-(1009)(1062)}{\sqrt{\left.\left\{(22.46839)-(1009)^{2}\right\}\{22.51412)-(1062)^{2}\right\}}}
\end{aligned}
$$




$$
\begin{aligned}
& r_{x y}=\frac{1077450-1071558}{\sqrt{(1030458-1018081)(1131064-1127844)}} \\
& r_{x y}=\frac{5892}{\sqrt{(12377)(3218)}} \\
& r_{x y}=\frac{5892}{\sqrt{39829186}}=\frac{5892}{6311,03} \\
& r_{x y}=0,93
\end{aligned}
$$

Untuk lebih mempermudah dalam memberikan interpretasi terhadap koefisien korelasi antara pengaruh pemberian motivasi (X) dengan semangat hafalan al-Qur'an (Y), yaitu dengan melihat yang berada di bawah ini:

\section{Tabel 8}

\section{Pedoman Untuk Memberikan Interpretasi Terhadap Koefisien}

Korelasi

\begin{tabular}{|c|c|}
\hline Interval Kofesien & Tingkat Hubungan \\
\hline $0,00-0,199$ & Sangat Rendah \\
\hline $0,20-0,399$ & Rendah \\
\hline $0,40-0,500$ & Sedang \\
\hline $0,60-0,799$ & Kuat \\
\hline $0,80-1,000$ & Sangat Kuat \\
\hline
\end{tabular}

Sumber : (Sugiyono, 2015: 257)

Jadi, dengan melihat tabel diatas hasil penelitian hubungan antara pengaruh pemberian motivasi terhadap semangat hafalan Al-Qur'an siswi kelas X Agama 2 Madrasah Aliyah Al-Amiriyyah Blokagung Karangdoro Tegalsari Banyuwangi sebesar $(r=0,93)$ tergolong sangat kuat.

\section{Pengujian Hipotesis}

Sedangkan, untuk menyatakan besar kecilnya hubungan variabel $\mathrm{X}$ terhadap Y dapat ditentukan dengan rumus:

$$
K P=r^{2} \times 100 \%=0,93^{2} \times 100 \%=86 \%
$$


Artinya : hubungan antara pengaruh pemberian motivasi terhadap semangat hafalan al-Qur'an siswi kelas X Agama 2 Marasah Aliyah AlAmiriyyah Blokagung Karangdoro Tegalsari Banyuwangi sebesar 86\% dan sisanya $14 \%$ ditentukan oleh variabel lain.

Menguji signifikansi dengan rumus $t_{\text {hitung: }}$ :

$$
t_{\text {hitung }}=\frac{r \sqrt{n-2}}{\sqrt{1-r^{2}}}=\frac{0,93 \sqrt{22-2}}{\sqrt{1-0,93^{2}}}=\frac{4,15}{0,93}=4,46
$$

Kaidah pengujian:

Jika $t_{\text {hitung }} \geq t_{\text {tabel }}$, maka signifikan

Jika $\mathrm{t}$ hitung $\leq \mathrm{t}$ tabel, maka tidak signifikan

Berdasarkan perhitungan di atas dengan ketentuan tingkat kesalahan $\alpha=$ 0,05; $\mathrm{db}($ Dalam Distribusi $)=\mathrm{n}-2=22-2=20$ sehingga didapat $\mathrm{t}$ tabel $=1,725$. Kesimpulan: Ternyata $\mathrm{t}$ hitung $\geq \mathrm{t}$ tabel atau $4,46 \geq 1,725$

Artinya ada hubungan yang signifikan antara variabel $\mathrm{X}$ dengan $\mathrm{Y}$ atau ada hubungan yang signifikan antara pengaruh pemberian motivasi dengan semangat hafalan Al-Qur'an siswi kelas X Agama 2 Madrasah Aliyah Al-Amiriyyah Blokagung Karangdoro Tegalsari Banyuwangi Tahun Ajaran 2015/2016.

\section{H. Diskusi Dan Interpretasi}

Suatu hal yang menakjubkan bila kita merenungi kembali kitab Al-Quran yang berisi nilai dan aturan hidup manusia mampu dihafal oleh rang-orang mukmin. Bahkan orang non-Muslim pun ternyata bias menghafal Al-Qur'an meskipun niat dan motif menghafal Al-Qur'an berbeda-beda namun, yang membuat kita tercengang adalah sampai saat ini kita tidak menemukan sebuah kitab suci selain Al-Qur'an yang dapat dihafal dengan sempurna dan bahkan tidak mengalami perubahan sedikit pun. Sesuai dengan teori dimuka bahwa, pemberian motivasi sangat diperlukan untuk menunjang proses dalam menghafal Al-Qur'an karna motivasi memberikan dorongan yang sangat kuat terhadap para penghafal Al-Qur'an baik secara dhohir maupun batin, dengan demikian adanya pemberian motivasi perlu adanya agar dalam perjalanan menghafal Al-Qur'an bisa sesuai target dan penuh semangat dalam menyelesaikan hafalan Al-Qur'an, hal ini menunjukan bahwasanya pemberian motivasi terhadap siswi sangat diperlukan 
untuk menambah semangat hafalan Al-Qur'an. Hal tersebut dapat dibenarkan, sebab hasil penelitian yang penulis lakukan di Madrasah Aliyah Al-Amiriyyah Blokagung Banyuwangi menyatakan bahwa antara pengaruh pemberian motivasi dengan semangat hafalan Al-Qur'an terdapat hubungan yang sangat kuat.

Atas dasar yang diperoleh, maka data tersebut dapat digeneralisasikan pada populasi dimana sampel yang diambil siswi kelas X agama 2 Madrasah Aliyah Al-Amiriyyah dengan kata lain data tersebut mencerminkan kaadan populasi.

\section{Interpretasi}

Berdasarkan analisis data di atas diperoleh hasil sebagai berikut:

1. Dari $t$-test yang telah dilakukan untuk menguji signifikansi di dapat $t_{\text {hitung }} \geq$ $\mathrm{t}_{\text {tabel}}$, maka signifikan. Jadi nilai $\mathrm{t}_{\text {hitung }}=4,46$ lebih besar dari $\mathrm{t}_{\text {tabel }}=1,725$, maka ada pengaruh pemberian motivasi dengan semangat hafalan Al-Qur'an siswi kelas X Agama 2 Madrasah Aliyah Al-Amiriyyah Blokagung Karangdoro Tegalsari Banyuwangi Tahun Ajaran 2015/2016 dikategorikan signifikan.

2. Dengan melihat kaidah pengujian dengan menggunakan rumus product moment di dapat $r_{x y}=0,93$, maka disimpulkan ada hubungan yang kuat antara pengaruh pemberian motivasi dengan semangat hafalan Al-Qur'an kelas X Agama 2 Madrasah Aliyah Al-Amiriyyah Blokagung Karangdoro Tegalsari Banyuwangi Tahun Ajaran 2015/2016.

Dengan demikian maka permasalahan yang ada dapat terselesaikan, yaitu ada hubungan yang signifikan antara pengaruh pemberian motivasi dengan semangat hafalan Al-Quran siswi kelas X Agama 2 Madrasah Aliyah Al-Amiriyyah Blokagung Karangdoro Tegalsari Banyuwangi Tahun Ajaran 2015/2016. Dengan adanya pemberian motivasi dalam rangka menghafalkan Al-Qur'an untuk bisa membahagiakan kedua orang tua dan para guru serta menjaga Al-Qur'an agar tetap terjaga sampai akhir zaman, maka hubungan pengaruh pemberian motivasi dengan semangat hafalan Al-Qur'an siswi kelas X Agama 2 Madrasah Aliyah AlAmiriyyah Blokagung Karangdoro Tegalsari Banyuwangi Tahun Ajaran 2015/2016 menjadi sangat kuat. 


\section{Kesimpulan}

Berdasarkan penelitian yang telah kami lakukan di kelas X Agama 2 Madrasah Aliyah Al-Amiriyyah Blokagung Karangdoro Tegalsari Banyuwangi Tahun Ajaran 2015/2016, dapat disimpulkan bahwa :

1. Berlandaskan hasil jawaban responden atau questioner tentang pengaruh pemberian motivasi diperoleh skor rata-rata " 45,86 ", jika dikonsultasikan dengan kategori nilai skor berada di interval 38-50 memiliki kategori "Baik". Maka pemberian motivasi dapat meningkatkan semangat hafalan Al-Qur'an.

2. Hasil jawaban responden atau questioner tentang semangat hafalan AlQur'an diperoleh skor rata-rata " 48,27 ”, jika dikonsultasikan dengan kategori nilai skor berada di interval 38-50 maka memiliki kategori "Baik".

3. Dari pengujian hipotesis yang telah dilakukan dengan menggunakan t-test, dan diperoleh $t_{\text {hitung }}=4,46$.Kemudian untuk melihat harga $t_{\text {tabel }}$, digunakan $\mathrm{db}=\mathrm{n}-2=22-2=20$. Dengan $\mathrm{db}$ (Dalam Distribusi) 20 dan taraf kesalahan 5\%, maka $t_{\text {tabel }}=1,725$. Maka $t_{\text {hitung }}$ lebih besar dari pada $t_{\text {tabel }}(4,46>1,725)$, sehingga Ho ditolak dan Ha diterima. Dengan demikian ada hubungan yang signifikan antara variabel $\mathrm{X}$ dengan $\mathrm{Y}$ atau ada hubungan yang signifikan antara pengaruh pemberian motivasi dengan semangat hafalan Al-Qur'an siswi kelas X Agama 2 Madrasah Aliyah AlAmiriyyah Blokagung Karangdoro Tegalsari Banyuwangi Tahun Ajaran 2015/2016.

\section{Daftar Pustaka}

Arikuoto, Suharsimi. 2006. Prosedur Penelitian Suatu Pendekatan Praktek. Jakarta: Rineka Cipta.

Amali Herry, Bahirul. 2012. Agar Orang Sibuk Bisa Menghafal Al-Qur'an. Yogjakarta: ProYo.

As'ad, H. Aliy. 2007. Terjemah Ta'limul Muta'alim. Kudus: Menara Kudus.

Hamalik, Oemar. 2011. Proses Belajar Mengajar. Jakarta: BumiAksara.

M. Noor Rohinah. Orang Tua Bijaksana, AnakBahagia. Yogjakarta: Katahati.

Purwanto, M. Ngalim. Prinsip-prinsip dan Teknik Evaluasi Pengajaran. Bandung: Remajan Rosdarika.

Syarifuddin, Ahmad. 2004. Mendidik Anak, Membaca, Menulis, dan Mencintai Al-Qur'an. Jakarta: GemaInsani. 
Jurnal Darussalam; Jurnal Pendidikan, Komunikasi dan Pemikiran Hukum Islam

Vol. IX, No 1: 122-147. September 2017. ISSN: 1978-4767 (Cetak), ISSN: 2549-4171 (Online)

Sugiyono. 2015. Metode Penelitian Pendidikan Pendekatan Kuantitatif, Kualitatif, dan R\&D. Bandung: Alfabeta.

Sudrajat \& Subana. 2005. Dasar-dasar Penelitian Ilmiah. Bandung: Pustaka Setia.

Uzer Usman, Moh. 2008. Menjadi Guru Profesional. Bandung: Remaja Rosdakary. 